\title{
Correction to: Positive effect of AgNPs and AuNPs in in vitro cultures of Lavandula angustifolia Mill.
}

\author{
Paula Jadczak $^{1}$ (D) Danuta Kulpa ${ }^{1} \cdot$ Magdalena Bihun $^{2} \cdot$ Włodzimierz Przewodowski $^{3}$
}

Published online: 4 June 2021

(c) The Author(s) 2021

\section{Correction to: \\ Plant Cell, Tissue and Organ Culture (PCTOC) (2019) 139:191-197 \\ https://doi.org/10.1007/s11240-019-01656-w}

The plant height data was missing in Table 1 in the initial online publication. The original article has been corrected.

Open Access This article is licensed under a Creative Commons Attribution 4.0 International License, which permits use, sharing, adaptation, distribution and reproduction in any medium or format, as long as you give appropriate credit to the original author(s) and the source, provide a link to the Creative Commons licence, and indicate if changes were made. The images or other third party material in this article are included in the article's Creative Commons licence, unless indicated otherwise in a credit line to the material. If material is not included in the article's Creative Commons licence and your intended use is not permitted by statutory regulation or exceeds the permitted use, you will need to obtain permission directly from the copyright holder. To view a copy of this licence, visit http://creativecommons.org/licenses/by/4.0/.

Publisher's Note Springer Nature remains neutral with regard to jurisdictional claims in published maps and institutional affiliations.

The original article can be found online at https://doi.org/10.1007/ s11240-019-01656-w.

\section{Paula Jadczak}

paula.jadczak@zut.edu.pl; paulajadczak@gmail.com

1 Department of Plant Genetics, Breeding and Biotechnology, Faculty of Environmental Management and Agriculture, West Pomeranian University of Technology in Szczecin, Słowackiego 17, 71-434 Szczecin, Poland

2 Molecular Biology and Biotechnology Center, Laboratory of Environmental Research, University of Szczecin, Małkocin 37, 73-110 Stargard, Poland

3 Plant Breeding, Acclimation Institute in Bonin National Research Institute, Poland, Bonin 3, 73-009 Bonin, Poland 